\title{
反復する娟道膜炎を伴う内耳奇形
}

\author{
村田 清高・老木 浩之・磯野 道夫 \\ 太田文彦
}

\section{Congenital Ear Anomalies and Idiopathic Fistula of the Oval Window Associated with Recurrent Meningitis}

\author{
Kiyotaka Murata, Hiroyuki Oiki, Michio Isono \\ and Fumihiko Ohta \\ (Kinki University)
}

Two cases of Mondini maldevelopment with recurrent meningitis are described. Cerebrospinal fluid leakage was observed to be coming from the anterosuperior margin of the oval window in one case and from a bone defect in the center of the footplate in the other. Removing the stapes and obliterating the vestibule with muscle, fascia and Lyodura proved to be satisfactory treatment. High resolution CT scanning of the temporal bone has brought definite diagnostic progress in finding ear anomalies. Congenital ear anomalies and fistula of the oval window should be included in the differential diagnosis of recurrent meningitis.

\section{はじめに}

耳性髄膜炎は真珠腫，中耳炎の急性増悪，メマイ，聴力障害などの際立った臨床所見を伴うこと が多い1)。しかし，奇形があり髉液が中耳，上咽頭と交通し髄膜炎を反復するあのはまれで，術前 診断も容易でないことがある，とくに奇形，中耳炎が確認できない場合はそうである．一般的には 内耳奇形は治療の対象之はならない。しかし，反復性髄膜炎で内耳奇形がある場合，先天的な髄液 瘦の存在を疑わなければならない22.

近年, 高空間分解能をむつC Tの出現により， 内耳奇形の詳細な把握が可能となった ${ }^{324)}$.

今後，いろいろの内耳奇形に伴う骾液漏が見られ，それらに対して適確な診断を行って，それに 応じた処置を行う機会が増えてくると考えられる，てのような理由から，内耳奇形に伴う反復性䯣 膜炎に対する演者らの診断, 治療の経験を報告し, 䯣液㾇の原因, 閉鎖法およびその問題点につい て考察したい.

近畿大学医学部耳鼻咽喉科学教室（主任：太田文彦教授） 
症

症例 1. 13歳, 男,

主 訴：反復する骾膜炎.

家族歴：特記すべきととなし.

既往歴： $2 \sim 3$ 歳頃流行性耳下腺炎および左 右不明だが中耳炎を 2 回惟った。 6 歳の頃落ち つきがないと精神科を受診したことがある。小 学 1 年の 5 月頃軽四輪車の側面に衝突した。意 識障害, メマイはなかった，小学 2 年のとき聴 力検查で左聴力がないといわれ某医でアデノイ ド切除術と副鼻腔炎の治療をうけた。

現病歴：昭和 55 年 8 月 22 日急に頭痛, 発熱

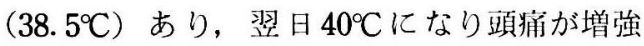
し，嘔吐が頻回におこった。このとき耳痛はな かった，原因がわからず治癒しないため昭和 55 年10月 6 日〜同年 11 月 9 日まで某聮院に入院 し, 精查後 streptococcus pneumoniae による 化膿性䯣膜炎が確定診断され治療をうけた。そ の後同様の症状が出現したので眧和56年11月 20 日から40日間，次いで昭和57年 2 月 19 日から再 発のため同院に入院治療した。

䯣液培萑菌は streptococcus pneumoniae で 動脈血, 咽頭粘液から屯同菌が確認された。ア
例

ミノ配糖体, ampicillin の投与により 1 週間で 䯣膜炎の怔状が改善し髄液培荃菌屯陰性となっ た. その後昭和 57 年 3 月 30 日著者らの耳鼻科を 受診した。髄液からの検出紐菌はいずれの再発 のときむ streptococcus pneumoniae であっ た.

耳鼻科入院時所見：髄膜炎の所見はなくなっ ていた。鼓膜，鼻腔，鼻呐頭に異常を認めなか った. Schüller, Stenvers 撮影で左内耳の発育 不全が疑われ左側䆍であった。高空間分解能を もつ側頭骨 C Tでは耳胞および不完全な前半規 管を確認できるが，後および外側半規管は全く なく，蝸牛の帅成もほとんどなかった耳䛌の 一部に骨壁を欠き, 軟部組織が直接中耳に面し ていた（㲸 1 ）。この骨矢損部よりの感染を疑 い昭和57年 4 月 1 日全身麻酔下に手術を施行し た。

手術所見：左耳後部皮膚切開にて皮下在剝離 し骨膜へ達したが，炎症その他の特别な異常所 見はなかった。正常に見える乳様突起を乳突洞 へ向って削開在始めた途端, 含気蜂夈から搏動 性の透明な水様性湧出をみた。吸引して屯瞬時
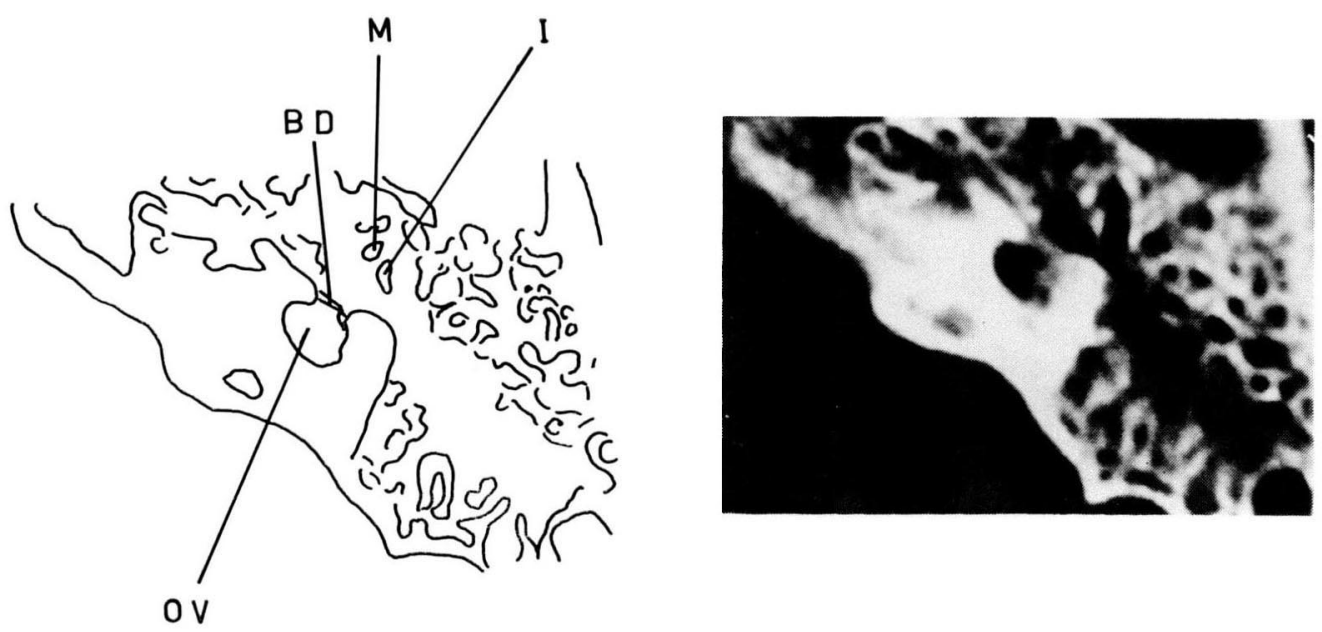

图 I 症例 1, 左側頭骨水平断面.

OV：空洞様内耳, B D : 骨欠損, M：ツチ骨, I : キヌタ骨 
に溢れた。含気蜂巣の発育はよく，炎症所見は なかった。乳突洞へ到達すると水様液が Aditus ad Antrum の方より湧出するのが確認さ れた. 勈出が早く大量のため，精査のための手 術続行が困難であったので，外耳道後壁を除去 し，上鼓室を開放し，キヌタ，アブミ関節を離 断しツチ，キヌタ骨を摘出した。ツチキヌタ 骨の形態に異常はなかった，鼓室内は殆んど含 気蜂巣のみで迷路骨包は殆んどなく，アブミ骨 上部で顔面神経鞘が一部露出していた，髄液湧 出源をさがすとアブミ骨周囲より流出が著明で あった．流出が大量のため視野がえられず，そ のためアブミ骨筋腱を切断し，錐体隆起を除去 し，湧出源をさらに追求した．正円空简を認め ず，アブミ骨より前部は骨壁を欠き硬膜様の外 観であった（図 2 )。この白い膜様部は C Tで 確認した耳胞の骨欠損部に一致した。䯣液の湧 出源は卵円空窩の前部にある小さな骨欠損部か らで，アブミ骨底板前部に相当していた．流出 する液の採取を試みたが大量湧出で血液も混入 するため成功しなかった．アブミ骨底板を除去 すると内部に小さな白い膜様組織塊が付着して きたので，乙れを含めて摘出した．前庭空内部 は空洞様であった，液を吸引すると瞬時内腔は
空になり，一呼吸おいて再び大量の液が涌出し てきた。

Lyodura $^{R}$ に Biobond ${ }^{R}$ 老つけて卵円空に あて閉鎖した。これを 2 個あてその外倒をさら にオキシセルとビオボンドをまぜたもので被い 圧迫して防水効果を強めた。しばらく外から綿 球で圧迫して煘液漏が止まった後，オキシセル はできるだけ除去した。

術後タンポン压迫による軽度の顔面神経麻痷 があり，また耳後部開放創の閉鎖むかねて昭和 57 年 4 月 22 日左顔面神経減荷術之 meatoconchoplasty 施行した。顔面神経は錐体部より ほとんど水平に前方へ走り外耳道の直下を通り 側頭骨外へ出ていた。水平部より末梢の神経鞘 は蒼白であったが表面の血流は維持されてい た。神経鞘を切開した。

術後水栐性の分泌物らしく思われたので昭和 57 年 4 月 24 日再手術を行った。前庭空閉鎖の人 工硬膜は殆んど変化せず残っていたが水様液の 漏れがごくわずか認められたので再び前庭空を 開放して，顔面神経にできるだけさわらぬよう に軟骨膜つきの耳珠軟骨を入れ前庭空を閉鎖 し, 外から筋膜でカバーした。顔面神経線維が 露出していたので按着剂を使用しなかった。開
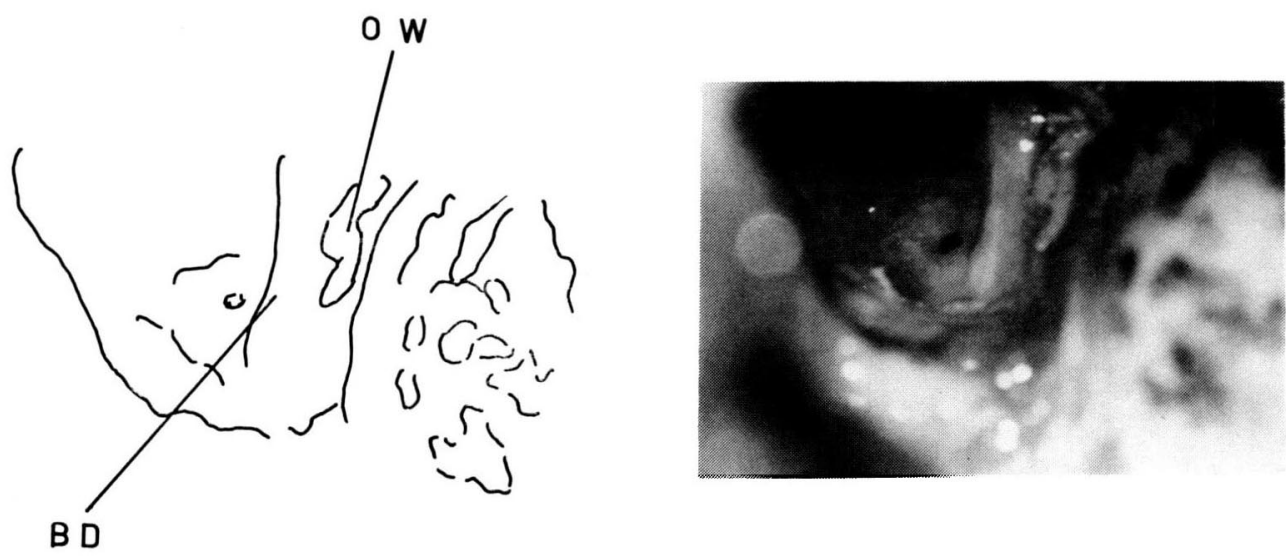

図 2 症例 1 , 左耳手術所見.

B D : 内耳の骨壁欠損部， OW：卵円空窩. 人工硬膜で閂鎖. 
放創整にはスポンゼルとタンポンを充填した。

術後 2 年半経過したが再発はない.

症例 2.4 歳, 男,

主 訴: 反復する髅膜炎.

家族歴：特記すべきことなし.

既往歴：1歳10力月の時腸炎の診断で某医院

に入院し 5 日間治療した。

現病歴： $40^{\circ} \mathrm{C}$ 以上発熱にて某医大に昭和 54 年11月 3 日から同年12月22日まで入院して, 䯣 液より肺炎球菌を検出されて化膿性䯣膜炎とし て治療をうけた。退院後も $37.5^{\circ} \mathrm{C}$ 程度の体温が 続いていた。昭和 55 年 2 月 23 日から同年 5 月 29 日まで, 高熱, 湢吐, 意識障害などの症状あり 入院した。このときも随液から肺炎球菌が検出 された．抗生物質の治郞にて $37^{\circ} \mathrm{C}$ まで熱し諸 症状古消失した。 以後 $37^{\circ} \mathrm{C}$ 程度の体温が続いた が特に異常に気づいていない. 笑然嘔吐に始ま る再発性骴道膜炎のため昭和56年10月23日から同 年12月 8 日まで某市民病院に入院し治療をうけ た。このときも肺炎球菌が䯣液から検出され た。この頃より両側側頭部痛を泝えるようにな った，その後両側側頭部痛, 㗊吐, 項部硬古な どの症状にて昭和 57 年 2 月 19 日より同年 3 月 19 日まで，昭和57年 5 月 7 日より同年 5 月 29 日ま で, 昭和57年 8 月 7 日より同年 8 月 30 日まで,
昭和 57 年10月15日より同年11月11日までの入院 治療を繰り返している．同年11月11日著者らの 耳鼻科に入院した。

耳鼻科入院時所見 : 耳介, 外耳道, 鼓膜所見 は成常であった。鼻咽喉顔面に異常なかった。 左側襲で，水水にも反応なく，高空間分解能側 頭骨 C Tでは半規管の発育がなく，耳胞および 蝸牛の始まりが認められるのみであった（図 3 ).

䧓道液漏を確認するため ${ }^{111} \mathrm{I}_{\mathrm{n}}-\mathrm{DTPA} の 520 \mu \mathrm{ci}$ を腰椎穿刺により䯣腔内に注入し，経洔的に耳 管咽䫓口における放射能の变化をしらべた（図 4 )。横軸は時間経過を縦軸は放射能の毎分力 ウント数をあらわす。11時間後に耳管咽頭口で 異常な放射能を測定し，濄液が中耳から耳管を 経て咽頭へ排出されたことを確認した。そこで 能迹液㜢確認のため昭和57年11月25日中耳を開放 した.

手術所見：全身麻酔下に左耳後部切開を加え 乳様突起を露出後 Zaufal 法に準じて乳突润を 削開した。乳突洞へ到達しても水様性の湧出を 認めなかった．外耳道後壁を除き上敋公を精査 した。ツチ，キヌタ骨の形態に異常なかった。 キヌタ,アブミ関節を離断し，ツチキヌタ骨 摘出し, 鼓膜を剥離反転して鼓室を精査した。
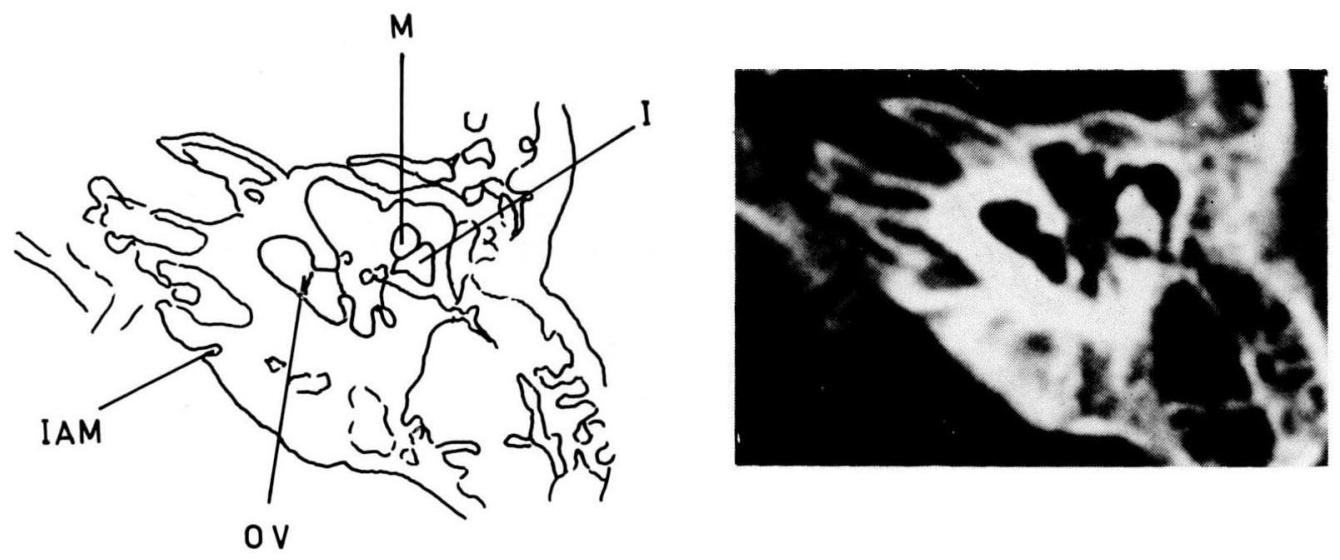

図 3 症例 2 , 左側頭骨水平断面.

I AM：内耳道 


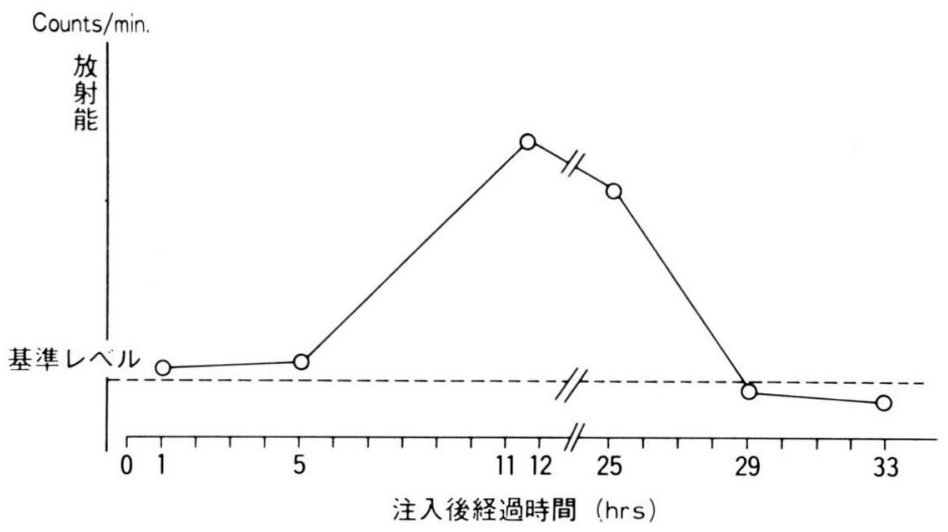

図 4 症例 $2,{ }^{111} \mathrm{In}-\mathrm{DTPA}$ 髄液注入後耳管咽頭口で検出された放射能.

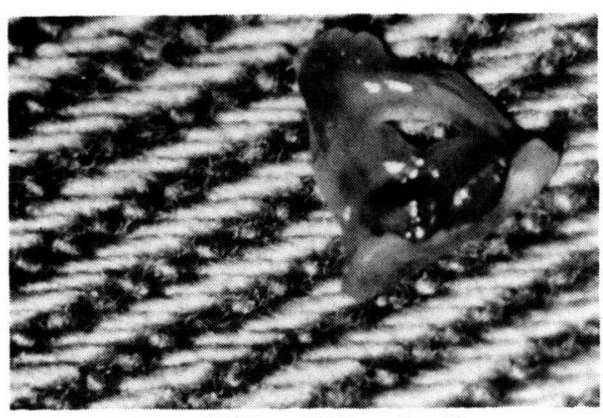

図 5 症例 2 , 摘出アブミ骨. 底板中央に骨欠損をみとめる。

耳管周囲から下鼓室の発青はよいが州的所見は なく，蝸牛は丸く小さかった。顔西神経管は水 平部でアブミ骨上部で骨壁の久損を認めた。ア ブミ骨の両脚の間から水泡様に薄い膜で内容 は透明な液体を含むものが突出していた。水泡 より内側は視野に入らなかった。 ての時点で水 様性の漏れを認めなかった。そのためての水泡 状の突出とアブミ骨を全体として閉銷するてと にし，人工硬膜とビオボンドで重畕し被った。 さらにその外側をオキシセルとビオボンドで補

考

著者らの調査しえた文献で確実に内耳奇形を 伴う髅液漏17例および内耳奇形の有無にかかわ らず能液漏を示した38症例について，クモ膜下 腔と中耳腔との交通路をしらべた（図6）。こ
強した。鼓空，乳突润は外耳道へ開放创とし た。

術後 3 週間すると耳内に水様性䯙液漏が出現 し，目然停止しないため，昭和58年 2 月 17 日再 び瘦孔閉鎖を試みた。鼓室内は前回の手術によ る生体接着剂とオキシセルが一塊となって释痕 状であった。乙れを除去してアブミ骨へ達する と䯣液が両脚間より漏れているのが確認され た。アブミ骨を摘出すると耳胞内は白い膜様物 が見えたが，涌出する骾液のため詳細は不明で あった。側頭筋から採取した筋肉片を前庭公か ら耳胞内へ押しこんだ。数個の筋肉片を追加し て押しこむと能液漏は止まった，鼓空に筋肉片 を充填し，さらにその外側在側頭筋前有荠弁で 充填した。

meatoconchoplasty を行い耳後部を縫合し て手術を終了した。摘出したアブミ骨は底板に 部分的欠損を生じており（図 5 )，乙の欠損よ り髄液の漏れがあったことが確認された。

術後 1 年10力月 経過したが再発はない.

按

れをみると前庭空からの䯣液漏が多いのがわか る，先天性骾液漏はまれだが，襲であって反復 性䯙膜资を伴う場合には, 内耳奇形之髄液漏に ついてよくさがさなければならない。すなわち 


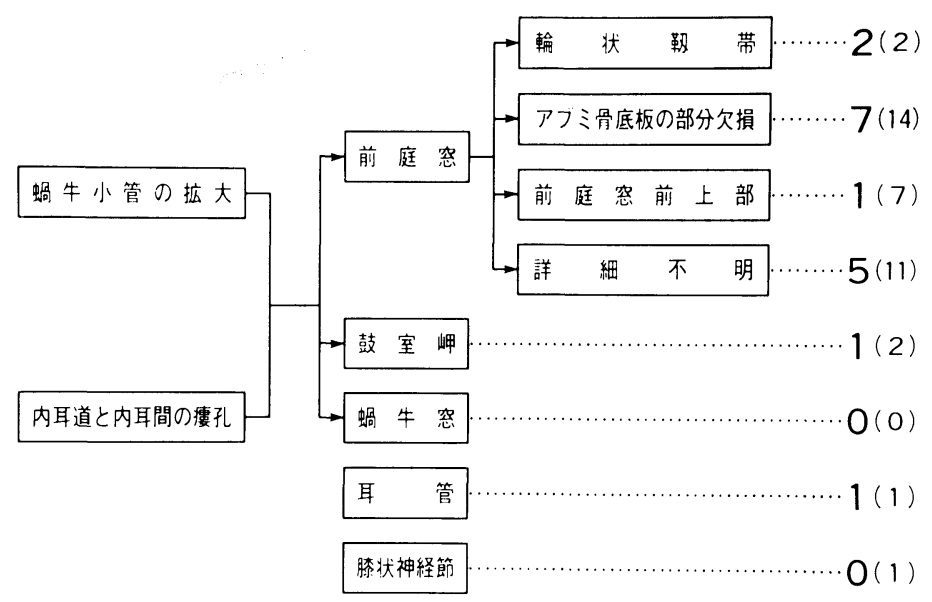

図 6 内耳奇形に伴うクモ膜下腔と中耳腔の交通.

（）内は内耳奇形の有無にかかわらず髄液漏の漏出部を記載したもの.

反復性髄膜炎の場合，たとえ中耳炎や䯣液漏が なくても，内耳奇形の精査が必要である。むし 奇形があれば㭪液との連絡を疑うべきであり， それには高空間分解能をもつC T が有用であ $3^{334)}$ 。䯣液漏を伴う中耳の奇形ではアブミ 骨奇形5(6)7) が報告されているが，内耳奇形で は7) 迷路の部分的あるいは全体的な空洞様発青

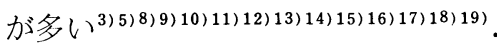

1.内耳奇形に伴う反復性䯣膜炎の原因

内耳奇形を伴う髄液漏では，䯣液之中耳之の 異常な連絡路があり, 発生異常が関与している と推測される，供覧した症例のような前庭空を 介する髄液漏が最む多く報告されており，アブ ミ骨底板の部分的欠損, 前庭空前上部瘦孔など が胃られる。乙の原因として一般に蝸牛小管の 拡大 ${ }^{14)}$ 20) 21) 22) や内耳道己内耳間の瘻孔を介し $て^{14)}$ 内耳压が上昇し，輪状勒带，アブミ骨底 板，前庭空前小裂開存などに瘻孔を生ずると説 明されている ${ }^{23) 2425) 26)}$. 一方アブミ骨の発生途 上に骨の吸収がアブミ骨底板の外層へおよぶ 際, otic capsule 由来の軟骨層へ屯扰よんで アブミ骨底板に欠損を生ずるという説明もあ

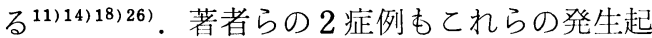
点に由来するものと考えられる。

前庭空前小裂はアブミ骨底板に近い前方から
発し enchondral bone 内へ進んでおり ${ }^{27)}$ ，乙 の開存が症例 1 と関連あるかむしれない。

また Mayer ${ }^{28)}$ が初めてヒトの側頭骨で microfissure を記載して以来多くの報告があ るように，中耳腔と内耳との間には微細間隙が 存在する可能性があり，乙れよりの感染が反復 して䯣膜炎の原因の 1 つになりうる。

症例 1 では，確かに骾膜炎であると診断され たのが10歳 7 力月からである。したがって先天 性内耳奇形々今回発見された䯣液漏之関連づけ るのは難しいのではないかという疑問が生じ る。この点に関しては以下のように理解でき る.

第 1 に，乙れ以前にも不明の発熱を経験して いるうえ，おちつきがなく精神科を受診させた ことなど不明膫な既往がある。したがって10歳 7 力月まで全く䯣膜刺激症状がなかったかどう かわから側面がある。

第 2 亿著者らの涉猟しえた文献から考える と，少なくとも内耳奇形と卵円空上りの䯣液漏 を認めた症例で 5 歳以上を拾ってみると， 17 歳 ${ }^{29)}, 7$ 歳 ${ }^{30)}, 9$ 歳 ${ }^{13)}, 6,10$ 歳 ${ }^{14)}, 12$ 歳 $^{18)}$, 10歳9)，17歳 ${ }^{31) ， 7}$ 歳 ${ }^{32)}$ な゙が報告されてい る。このうち外傷の記載が明瞭なものは少な

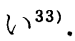


前述の如く事実内耳奇形を伴う卵円空からの 䯣液漏之反復性髄膜炎の早期発見例が多数ある ことからあ, 内耳奇形と䯣液漏は合併症として 認識されるべきであると考える。

2. 中耳と頭蓋腔との交通

反復性髄膜炎の原因となった交通路は

(1)先天性迷路周囲髅液漏そのうち (1) Hyrtl's fissure $=$ hiatus tympanomeningeal（これは蝸 牛の下で正円空の下に開く)，(2)顔面神経管， (3)錐体乳笑管の開存, (4)蝸牛空, 前庭空, (2)側 頭骨骨折，(3)手術による外傷，(4)真珠腫性中耳 炎, (5)脳動静脈奇形，(6)腫瘍による骨破壊，な よ゙がある ${ }^{34)}$.

3 . 髅液漏の診断

䯑道液であることを直接証明する必要がある。 これには以下の方法がある。

(1)糖の測定

䯣液の糖濃度は中耳渗出液より高いことを鑑 別に利用する。乙れには糖に敏感に反応する glucose oxidase test を利用するとよい.

(2)内視鏡

近年発達した微小硬性内視鏡（針状硬性鏡） を用い中耳を直接観察し, 骾液の漏れる様子を 直接確認できるとともある.

(3)RI cisternography, Isotope encephalography

${ }^{111}$ In-DTPA のような放射性同位元素を使っ て scintiscan, scinticamera で髄液漏を確認 する万法むよく使われる。䯣液中へ放射性同位 元素を注入し, 経時的に中耳あるいは耳管咽頭 口などの放射能を測定して，乙の部に異常に高 い放射能を確認することにより，䯣液漏である 有力な証拠になる。症例 2 ではこの方法を用い て䯣液漏であることを診断した。

1964年 Dichiro ${ }^{36)}$ によって開発された ${ }^{131} \mathrm{I}$ 〔RIHSA〕は aseptic meningitis があるの で, ${ }^{99 \mathrm{~m}} \mathrm{Tc}$-albumin, ${ }^{169} \mathrm{Yb}$-DTPA, ${ }^{111} \mathrm{In}$-DTP A などが最近使われている.

3 者を比較すると, ${ }^{99 \mathrm{~m}} \mathrm{Tc}-$ albumin は半減 期が 6 時間であるので資料を採取しておいて後
でカウントする場合は具合が悪い. ${ }^{111} \mathrm{In}$ は半 減期が67.4時間であり，乙の点で有利である. また, ${ }^{169} \mathrm{Yb}-\mathrm{DTPA}$ は ${ }^{111} \mathrm{In}$ に較べて被曝が 多い，以上の理由で今回の症例では ${ }^{111}$ In-DTP $\mathrm{A}$ が使用された。因みに ${ }^{131} \mathrm{In},{ }^{99 \mathrm{~m}} \mathrm{Tc}$ は髄液に 流入すると血中へ出て鼻粘膜へ達する。 ${ }^{169} \mathrm{Yb}$ は尿のみから排泄される。

(4)造影剂

造影剂による cisternography あるいは断層 撮影，CTスキャンなどにて髄液の漏れを捕捉 できるととあある.陽性油性造影剂Pantopaque をクモ膜下腔や脳室内に注入し漏出部を発見す るために使用された。しかし， cisternography で造影剂を入れるとケイレンその他の副作用が おこることが最近わかり，ほとんど使用されな くなった.

(5)色素

種々の色素類, 例えば methylen blue, indigo carmine ${ }^{8 / 26) 29(30)}$, PSP, fluorescin ${ }^{6 / 14) 19)}$ を䯣液中へ注入することは，神経系への毒性， 髄膜への刺激などで，現在使われなくなってい る。

\section{4. 䯣液漏の処置}

診断が確定すると外科的に髄液漏の源へ到達 し，乙れを閉鎖する必要がある。

その際使用される閉鎖材料には，側頭筋およ び筋膜, 耳後部結合織, 脂肪などの生体組織の ほ加に工的材料として人工硬膜 Lyodura ${ }^{\circledR}$, 生体接着剂 (cyanoacrylate, ヒト濃縮フィブリ ン)，オキシセルロース (oxycel $\left.{ }^{\circledR}\right)$, collagen sponge，吸収性 gelatine sponge，などがあ る.

閉鎖場所をみると，内耳道にてれらの材料を 充填して内耳道クモ膜下腔と内耳との連絡を絶 つ方法 ${ }^{78}{ }^{89}{ }^{29}$ 37), 前庭空を外仍ら压迫カバーす る方法 ${ }^{39}$ (40)，アブミ骨を除去し前庭空を閉鎖す る方法 ${ }^{10)}{ }^{251}$, 前庭空より前庭へ閉鎖材料を充填 する方法2 (5) 6) 9) 11) 12) 13) 14) 16) 26) 30) 31) 32) 41) 42) あるい は中耳全体を充填する方法 ${ }^{199}$ などの処置が行わ れている. 
迷路摘出術について考えてみると, 奇形耳な ので脳脊䯆液の流出口を広げる結果, 脳脊髄液 の流出が大量になると考えられ推奖できない.

アブミ骨底板の除去について考えてみると今 回の 2 症例の如く，乙れを除去して前庭内へ筋 肉弁充填あるいは人工硬膜と接着剂によって閉 鎖を行うと有効である。しかし除去しない場合 症例 2 の如く再発しやすい.

著者らの 2 例はともに，アブミ骨を摘出して 前庭空閉鎖を行うことで䯣液漏を止好るとが できた，前庭空からの髄液漏にはこの方法が最 善であろうと考えている，乙の際留意すべきこ とは顔面神経を損傷しないととである。という のは，アブミ骨上部の顔面神経管はしばしば骨 壁を欠くからである ${ }^{43)}$ 。そのため今回は再手術
では生体接着剂を使用していない。しかし，生 体接着剂と人工硬膜で髄液漏を止好るう法の有 用性については著者らも別症例で確認してい る.

Rice $^{11)}$ は1967年卵円空よりの随液漏症例に 内耳奇形の存在を推測しているが実証できてい ない.

近年側頭骨 C T の診断技術の向上により内耳 奇形の診断精度が向上した。そのため内耳奇形 に伴う髄液漏は見逃してはならない瓷患になっ ている．今後診断技術の向上とともに，いろい ろの内耳奇形に伴う髄液漏が見られると思われ る. それらに対して適確な診断を行って，それ に㐫じた処置を行う機会が増えてくると考えら れ 2 症例を呈示した。

\section{ま と め}

Mondini 型内耳奇形を伴う反復性䯑道脱炎の 2 例を報告した。 1 例は卵冈空前上部より，他はア

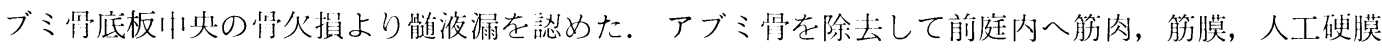
などを充填し，外侧を同様に䦌銷するう法が確実であることを述べた。

本論文の要旨は第84回日本耳鼻咽喉科学総会（1983年 5 月，大阪）でビデオ講演した。

\section{参考 献}

1) 山本和久, 永井 氾, 中村賢二, 山本洸一, 八木 沢幹夫，佐藤 茂：日本に扔ける最近の耳性頭蓋

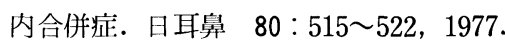

2 ) 村田清高, 細井裕司, 璣野道夫, 西前忠英, 西本 力，甲田嘉彦，太田文彦：反復する㗙膜炎を伴う 内耳奇形 (ビデオ). 日耳鼻 $86: 1315 \sim 1316$, 1983.

3 ) 村田清高, 細井裕司, 磯野道夫, 太田文彦: 内耳 奇形の 1 例一側頭骨 C Tによる診断. 耳鼻臨床 $75:$ 1047 1054, 1982.

4) 村田清高, 磯野道夫, 西前忠英, 玉木克彦, 細井 裕司, 太田文彦：側頭骨 C T 亿上万臨床部断. 耳 鼻臨床 $76: 424 \sim 434,1983$.

5 ) Barr B, Wersall J : Cerebrospinal otorrhea with meningitis in congenital deafness. Arch Otolaryngol 81:26 28, 1965.

6 ) Schultz P, Stool S: Recurrent meningitis due to a congenital fistula through the stapes footplate. Amer J Dis Child 120:553 554, 1970.

7) Kaseff LG, Nieberding PH, Shorago GW, Huertas G : Fistula between the middle ear and subarachnoid space as a cause of recurrent meningitis : Detection by means of thin section, complex-motion tomography. Neuroradiology $135: 105 \sim 108,1980$.

$8)$ Skolnik EM, Ferrer JL : Cerebrospinal otorrhea. Arch Otolaryngol $70:$ 795 799, 1959.

9 ) Bennett RJ : On subarachnoid-tympanic fistula. A report of two cases of the rare indirect type. J Laryngol Otol $80: 1242 \sim$ 1252, 1966.

10) Farrior B, Endicott JN : Congenital mixed deafness: cerebrospinal fluid otorrhea. Ablation of the aqueduct of the cochlea. Laryngoscope $81: 684 \sim 699,1971$. 
11) Rice WJ, Waggoner LG : Congenital cerebrospinal fluid otorrhea via defect in the stapes footplate. Laryngoscope $77: 341 \sim 349,1967$.

12) Vermeersch H, Kluyskens $P$, Vanderstock $\mathrm{L}$ : The temporal bone as route of infection in recurrent meningitis. J Otolaryng 9 : 199 201, 1980 .

13) Harrington JW, Birck HG : Recurrent meningitis due to congenital petrous fistula. Arch Otolaryngol $85:$ 128 131, 1967.

14) Desjardins R, Guerguerian AI, Dube J, Deschamps N, Lavertu P: Meningitis and congenital fistula of the internal ear. J Otolaryng II:97 100, 1982.

15) Hipskind MM, Lindsay JR, Jones TD, Valvassori GE : Recurrent meningitis and labyrinthine gusher, related to congenital defects of the labyrinthine capsule and stapes footplate. Laryngoscope $86: 682 \sim 689$, 1976.

16) Crook JP: Congenital fistula in the stapedial footplate. Southern Med J 60:1168 $\sim 1170,1967$.

17) Biggers WP, Howell NN, Fischer ND, Himadi GM : Congenital ear anomalies associated with otic meningitis. Arch Otolaryngol 97 : 399 401, 1973.

18) Parisier SC, Birken EA : Recurrent meningitis secondary to idiopathic oval window CSF leak. Laryngoscope $86: 1503 \sim 1514$, 1976.

19) Stool $S$, Leeds NE, Shulman $K$ : The syndrome of congenital deafness and otic meningitis: Diagnosis and management. J Pediat $71: 547 \sim 552,1967$.

20) Igarashi M, Schuknecht HF : Pneumococcic otitis media, meningitis and labyrinthitis. Arch Otolaryngol 76:126〜130, 1962.

21) Bauer E: Spontane Oto-Liquorrhoe auf Grund einer kongenitalen Missbildung des Aquaeductus cochleae. $Z$ Laryng Rhinol Otol 41:704 723, 1962.

22) Schuknecht HF, Seifi AE: Experimental observations on the fluid physiology of the inner ear. Ann Otol Rhinol Laryngol 72 : 687 712, 1963.

23) Goodhill V : Leaking labyrinth lesions, deafness, tinnitus and dizziness. Ann Otol Rhinol Laryngol $90:$ 99 106, 1981.

24) Goodhill V : Traumatic fistulae. J Laryng $94: 123 \sim 128,1980$.

25) Lahovary A : Congenital cysts of the oval window. HNO $26: 419 \sim 420,1978$.

26) Clark JL, DeSanto LW, Facer GW : Congenital deafness and spontaneous CSF otorrhea. Arch Otolaryngol $104: 163 \sim 166$, 1978.

27）側頭骨研究会編：ヒト側頭骨形態学アトラス. : 144, 1974.

28) Mayer O: Ueber die Entstehung der Spontanfrakturen der Labyrinthkapsel und ihre Bedeutung fuer die Otosklerose. Z Hals Nasen Ohrenheilk $26: 261 \sim 279,1930$.

29) Gundersen $T$, Haye R: Cerebrospinal otorrhea. Arch Otolaryngol 91:19 23, 1970.

30) Bottema $T$ : Spontaneous cerebrospinal fluid otorrhea. Arch Otolaryngol 101:693 694, 1975.

31）山川腙位，寺山吉彦：䯠膜炎を反復した内耳奇形 に対する C T Air Cisternography. 日耳鼻 $86: 1044,1983$.

32）斎藤龍介, 遠藤洋一，小林正尚，松村元良，増田 游, 林洋光: 特発性邻道液耳漏一㕼膜炎を反復した 特発性卵円空瘦孔の 1 例一. 耳喉 $51 ： 421 \sim 428$, 1979.

33) Althaus SR: Spontaneous and traumatic perilymphatic fistulas. Laryngoscope 87 : 364 371, 1977

34) Gacek R, Leipzig B: Congenital cerebrospinal otorrhea. Ann Otol Rhinol Laryngol $88: 358$ $\sim 365,1979$.

35）深町 彰：開放性宿没骨折を伴う髄液漏. 乙の症 例の診断のすすめ方と手術適応. 外科 $43: 1002$ 〜1007, 1981.

36) Dichiro G, Ommaya AK, Ashburn WL : Isotope cisternography in the diagnosis 
and follow-up of cerebrospinal fluid rhinorrhea. J Neurosurg 28 : 522 529. 1968.

37) Kaufman B, Jordan VM, Pratt LL : Positive contrast demonstration of a cerebrospinal fluid fistula through the fundus of the internal auditory meatus. Acta Radiol 9 : 83 90, 1969.

38) Rockett FX, et al: Pantopaque visualization of a congenital dural defect of the internal auditory meatus, special issue. Acta Radiol $9: 83 \sim 90,1969$.

39) Richards SH, Gibbin KP: Recurrent meningitis due to congenital fistula of stapedial footplate. J Laryng 9| : 1063 1071, 1977.

40) Ulso C, Hentzer E: Surgical treatment of recurrent perilymph fistula with anacusis. Ann Otol Rhinol Laryngol $89: 121 \sim 123$, 1980.

41）岩沢俊二，佐藤保生，野村恭也：化膿性㕼膜炎を 反復した特発性髄液漏の 1 例. 日耳鼻 $84: 541$, 1981.

42）水野正浩, 野村恭也, 平出文久, 森田 守: アブ 之骨底の瘦孔を伴った耳性跹液漏の 1 例. 耳喉 47 : 573 581, 1975.

42）村田清高, 斎藤春雄, 岡野安雅：鐙骨上部顔面神 経管の欠損について。臨床耳科 1：144，1974。

原稿到着：昭和59年10月11日

別刷請求先：村田清高

厂589 大阪府南河内郡狭山町西山 380

近畿大学医学部耳鼻咽喉科学教室 